• e ISSN-0976-6855 | Visit us : www.researchjournal.co.in

\title{
Evaluation of newer insecticides against leaf hopper on Bt cotton
}

\author{
P.W. NEMADE*, S.B. DESHMUKH AND JAYASHRI D. UGHADE ${ }^{1}$ \\ Cotton Research Unit, Dr. Panjabrao Deshmukh Krishi Vidyapeeth, AKOLA (M.S.) INDIA \\ ${ }^{1}$ Zonal Agriculture Research Station, YAVATMAL (M.S.) INDIA
}

\section{ARITCLE INFO}

Received : 09.07 .2015

Revised : 20.08 .2015

Accepted : 05.09 .2015

\section{KEY WORDS :}

Leaf hopper, Bt cotton, Fipronil, Imidacloprid, Diafenthiuron

*Corresponding author: Email: pwn.pdkv@gmail.com

\begin{abstract}
Evaluation studies were carried out for management of leaf hoppers on Bt cotton during 2012-13 at three different locations. The pooled results revealed that minimum population of leaf hoppers was recorded in the treatment fipronil $5 \mathrm{SC}(0.075 \%)$ and it was at par with treatment diafenthiuron $50 \mathrm{WP}(0.08 \%)$ and imidacloprid $30.5 \mathrm{SL}(0.005 \%)$. Next best treatment was buprofezin $25 \mathrm{SC}(0.05 \%)$. Significantly highest seed cotton yield of $19.43 \mathrm{q} / \mathrm{ha}$ was harvested in application of treatment fipronil $5 \mathrm{SC}(0.075 \%)$ followed by diafenthiuron $50 \mathrm{WP}(0.08 \%)$ and imidacloprid $30.5 \mathrm{SL}(0.005 \%)$ with 18.66 and 18.19 quintal per hectar, respectively. Highest monetary return Rs. 33,409 per ha was also observed in the treatment fipronil $5 \mathrm{SC}(0.075 \%)$ followed by imidacloprid 30.5 SL (0.005\%) (Rs. 30113 per ha) and diafenthiuron 50 WP (0.08\%) (Rs. 28340 per ha) whereas in terms of higher incremental cost benefit ratio, imidacloprid $30.5 \mathrm{SL}(0.005 \%)$ was found superior which recorded 1: 13.3 followed by fipronil $5 \mathrm{SC}(0.075 \%)$ (1: 8.9).
\end{abstract}

How to view point the article : Nemade, P.W., Deshmukh, S.B. and Ughade, Jayashri D. (2015). Evaluation of newer insecticides against leafhopper on Bt cotton. Internat. J. Plant Protec., 8(2) : 313-318. 